\title{
China Beamed Confidence into Economic Globalization on WEF
}

Keyao Zhang

Beijing Correspondent

\section{Introduction}

On January 15-18, 2017, President Xi Jinping visited Davos, Switzerland to attend the annual meeting of the World Economic Forum ("WEF"). He delivered a keynote speech at the opening plenary. Xi has beamed the much-needed confidence into the global economy amid grave concerns over rising protectionism and uncertainties in the wake of Brexit and the new US President Donald Trump gaining power. ${ }^{1}$

\section{Protectionism v. Engaged Globalization}

At the WEF, President Xi illustrated the objective necessity of economic globalization. Over the centuries, economic globalization has powered global growth and facilitated movement of goods and capital, advances in science, technology and civilization, and interactions among peoples. ${ }^{2}$

Economic globalization was once viewed as the treasure cave in The Arabian Nights, but now it has become the Pandora's Box in the eyes of many. ${ }^{3}$ Some people blame economic globalization for bringing the chaos to the world. The US - once a top promoter of economic globalization - has adopted an inward-looking posture when the new President Trump is leading his administration to an antiglobalization road. The European Union ("EU") has been badly hit by Brexit and throws its own globalization experiment into doubt. ${ }^{4}$

Though economic globalization is a "double-edged sword" and has created new problems, there is no justification to consider economic globalization off completely. Populism, isolationism and protectionism on rise in the Western world 
are related to politics that are wrapped up in economic problems and resulting in growing social fragmentation. An anti-globalization cry only reflects a shortage of globalization itself. ${ }^{5} \mathrm{As} \mathrm{Xi}$ said, "pursuing protectionism is like locking oneself in a dark room. While wind and rain may be kept outside, that dark room will also block light and air."

Analyzing the root causes of the sluggish global economy and the problems for which globalization has been made the scapegoat, Xi pointed to a lack of robust driving forces for global growth, inadequate global economic governance, and uneven global development. ${ }^{7}$

President Xi warned that any moves to turn back to protectionism runs against historical trend. He claimed:

\begin{abstract}
Whether you like it or not, the global economy is the big ocean from which you cannot escape. Any attempt to cut off the flow of capital, technology, products, industries and people between economies, and channel the waters in the ocean back into isolated lakes and creeks is simply not possible. ${ }^{8}$
\end{abstract}

Though globalization has faced with structural difficulties, Xi, pointing out China's successful experience, emphasized the necessity of "swimming in the ocean" of the world market and proactively adapting to globalization. Figures show that China is not only the beneficiary of economic globalization, but also a contributor to it. ${ }^{9}$ China's development offers opportunities to business communities in other countries.

\title{
Prospect
}

No one will emerge as a winner in a trade war. Therefore, the right way forward is to guide economic globalization, cushion its negative impacts, and deliver its benefits to all countries.

Xi said: "In the face of both opportunities and challenges of economic globalization, the right thing to do is to seize every opportunity, jointly meet challenges and chart the right course for economic globalization." As finding the right path to globalization is the only rational option, the roadmap Xi has offered could be the wave of the future.

President Xi Jinping offered a series of proposals at the WEF on how to deal 
with global challenges. He called for joint efforts to shoulder the responsibility of the times and promote world development. There is a fundamental need to develop a dynamic innovation - driven growth model, one that is well - coordinated and inter-connected, one that is win-win for all involved.

China will keep its doors widely open, hoping that other countries will also keep their doors open to Chinese investors and keep the playing field level for them. China will advance the building of a Free Trade Area in the Asia-Pacific and negotiations of the Regional Comprehensive Economic Partnership ("RCEP") to form a global network of free trade arrangements. Regarding the Belt and Road Initiative, envisioned as an infrastructure and trade network connecting Asia with Europe and Africa along ancient trade routes, China's circle of friends is growing larger, with the initiative delivering significant benefits. ${ }^{10}$

\section{REFERENCES}

1. Huaxia, Spotlight: Xi charts globalization course at Davos forum with Chinese plan, XINHUANET, Jan. 18, 2017, available at http://news.xinhuanet.com/english/2017-01/18/c_135993655.htm (last visited on Feb. 14, 2017).

2. Huaxia, Spotlight: Xi's Switzerland tour shows Chinese wisdom, confidence in face of sluggish global economy, anti-globalization sentiment, XINHUANET, Jan. 19, 2017, available at http://news.xinhuanet.com/english/2017-01/19/c_135997830.htm (last visited on Feb. 14, 2017).

3. “The treasure cave" 阿里巴巴的山洞 is found by Ali Baba in The Arabian Nights. See Xi Jinping, Jointly Shoulder Responsibility of Our Times, Promote Global Growth 共担时代责任 共促全球发展, Keynote speech at the Opening Session of the World Economic Forum Annual Meeting 2017, XinHUANET, Jan. 17, 2017, available at http://news.xinhuanet.com/2017-01/18/ c_1120331545.htm. English official version is available at http://www.scio.gov.cn/32618/ Document/1540505/1540505.htm (last visited on Feb. 14, 2017).

4. Huaxia, Spotlight: World needs more globalization, not less, Xinhuanet, Jan. 19, 2017, available at $\mathrm{http}: / /$ news.xinhuanet.com/english/2017-01/19/c_135997350.htm (last visited on Feb. 14, 2017).

5. Huaxia, Spotlight: World needs more globalization, not less, ХINHUANET, Jan. 19, 2017, available at $\mathrm{http}: / /$ news.xinhuanet.com/english/2017-01/19/c_135997350.htm (last visited on Feb. 14, 2017).

6. 搞保护主义如同把自己关进黑屋子, 看似躲过了风吹雨打, 但也隔绝了阳光和空气。See Xi supra note 3 . 
7. Huaxia, Spotlight: Xi charts globalization course at Davos forum with Chinese plan, XINHUA, Jan. 18, 2017, available at http://news.xinhuanet.com/english/2017-01/18/ c_135993655.htm (last visited on Feb. 14, 2017).

8. Xi, supra note 3.

9. "In the coming five years, China is expected to import 8 trillion U.S. dollars of goods, attract 600 billion dollars of foreign investment, and make 750 billion dollars of outbound investment, said the President, adding that Chinese tourists are expected to make 700 million overseas visits." See Huaxia, Spotlight: Xi's Switzerland tour shows Chinese wisdom, confidence in face of sluggish global economy, anti-globalization sentiment, XINHUANET, Jan. 19, 2017, available at http://news.xinhuanet.com/english/2017-01/19/c_135997830.htm (last visited on Feb. 14, 2017).

10. Xi, supra note 3. 